\title{
Rear Surface Optimization of CZTS Solar Cells by Use of a Passivation Layer With Nanosized Point Openings
}

\author{
Bart Vermang, Yi Ren, Olivier Donzel-Gargand, Christopher Frisk, Jonathan Joel, Pedro Salomé, \\ Jérôme Borme, Sascha Sadewasser, Charlotte Platzer-Björkman, and Marika Edoff
}

\begin{abstract}
Previously, an innovative way to reduce rear interface recombination in $\mathrm{Cu}(\mathrm{In}, \mathrm{Ga})(\mathrm{S}, \mathrm{Se})_{2}$ (CIGSSe) solar cells has been successfully developed. In this work, this concept is established in $\mathrm{Cu}_{2}(\mathrm{Zn}, \mathrm{Sn})(\mathrm{S}, \mathrm{Se})_{4}(\mathrm{CZTSSe})$ cells to demonstrate its potential for other thin-film technologies. Therefore, ultrathin CZTS cells with an $\mathrm{Al}_{2} \mathrm{O}_{3}$ rear surface passivation layer having nanosized point openings are fabricated. The results indicate that introducing such a passivation layer can have a positive impact on open-circuit voltage $\left(V_{\mathrm{OC}} ;+17 \%\right.$ rel. $)$, short-circuit current $\left(J_{\mathrm{SC}} ;+5 \%\right.$ rel. $)$, and fill factor $(\mathrm{FF} ;+9 \%$ rel.), compared with corresponding unpassivated cells. Hence, a promising efficiency improvement of $32 \%$ rel. is obtained for the rear passivated cells.
\end{abstract}

Index Terms-Aluminum oxide, $\mathrm{Cu}(\mathrm{In}, \mathrm{Ga})(\mathrm{S}, \mathrm{Se})_{2}, \mathrm{Cu}_{2}(\mathrm{Zn}$, $\mathrm{Sn})(\mathrm{S}, \mathrm{Se})_{4}$, nanosized point contacts, solar cells, surface passivation layer, thin-film.

\section{INTRODUCTION}

C ZTSSe and CIGSSe semiconductor materials exhibit comparable optical and electronic properties and are used in photovoltaic (PV) thin-film (TF) solar cells with similar structure but fairly different efficiency levels. Indeed, the CZTSSe kesterite and CIGSSe chalcopyrite structures are known to be associated with each other, where the advantage of CZTSSe lays in its composition of nontoxic and earth-abundant materials. Both of these p-type semiconductor materials are used as absorber layers in TF solar cells, combined with an n-type buffer layer and front and rear contact layers. At present, top

Manuscript received June 4, 2015; revised September 24, 2015; accepted October 22, 2015. Date of publication November 17, 2015; date of current version December 18, 2015. This work was supported by the Swedish Science Foundation (VR), the Swedish Energy Agency, and the European Commission via FP7 Marie Curie IEF 2011 under Action No. 300998. The work of B. Vermang was supported by the Flemish Research Foundation FWO (mandate $12 \mathrm{O} 4215 \mathrm{~N}$ ). The work of P. Salomé was supported by the European Commission through the FP7 Marie Curie IEF 2012 under Action No. 327367.

B. Vermang is with the Ångström Solar Center, University of Uppsala, Uppsala 75121, Sweden, with the Department of Electrical Engineering, University of Leuven, Leuven 3001, Belgium,and also with Thin Film Photovoltaics, IMEC, Leuven 3001, Belgium (e-mail: bart.vermang@imec.be)

Y. Ren, O. Donzel-Gargand, C. Frisk, J. Joel, C. Platzer-Björkman, and M. Edoff are with the Ångström Solar Center, University of Uppsala, Uppsala 75121, Sweden (e-mail: yi.ren@ angstrom.uu.se; olivier.donzel-gargand@ angstrom.uu.se; christopher.frisk@angstrom.uu.se; jonathan.joel@ angstrom. uu.se; charlotte.platzer@ angstrom.uu.se; marika.edoff@ angstrom.uu.se).

P. Salomé, J. Borme, and S. Sadewasser are with the Laboratory for Nanostructured Solar Cells, International Iberian Nanotechnology Laboratory, Braga 4715-330, Portugal (e-mail: Pedro.Salome@inl.int; jerome.borme@inl.int; sascha.sadewasser@inl.int).

Color versions of one or more of the figures in this paper are available online at http://ieeexplore.ieee.org.

Digital Object Identifier 10.1109/JPHOTOV.2015.2496864 conversion efficiencies for small-area CIGSSe solar cells are typically above $20 \%$ (e.g., NREL, ZSW, HZB, EMPA, Solibro, Solar Frontier, etc.), whereas CZTSSe solar cells are limited to efficiencies slightly above $10 \%$ (e.g., IBM, Imec, IREC, Solar Frontier, etc.) [1].

The CIGSSe material quality is already high, which endorsed the introduction of innovative front and rear surface passivation concepts in recent years. In the past, CIGSSe solar cell research has mainly been focused on improving the absorber layer (e.g., by Ga grading, Na doping, etc.); as a result, efficiencies above $20 \%$ were realized. Such high-efficiency CIGSSe solar cells essentially have long charge carrier diffusion lengths, which means that the recombination of these charge carriers at-and thus passivation of - front and rear CIGSSe surfaces became a new topic of attention. On the one hand, the front interface of CIGSSe absorber layers has been improved by the introduction of 1) a front surface passivation layer or 2) a postdeposition treatment with potassium fluoride (KF). HZB used the sprayILGAR (ion layer gas reaction) deposition to fabricate $\mathrm{ZnS}$ nanodots embedded in an $\operatorname{In}_{2} \mathrm{~S}_{3}$ buffer layer, where the nanodots appear to reduce recombination at the front absorber interface [2]. However, EMPA also developed a technique that could generate a front surface passivation layer with nanosized point openings, namely the self-assembled alkali-templates approach where a well-controlled grid of $\mathrm{KF}$ islands $(<30 \mathrm{~nm})$ is grown [3]. Moreover, it has been shown that the $\mathrm{K}$ treatment itself already results in enhanced passivation of grain boundaries and donor-like defects (but enables thinning of the CdS buffer layer, increased junction depth, and increased bandgap as well) [4]. On the other hand, recombination at the standard Mo/CIGSSe rear interface of CIGSSe solar cells has been reduced in a similar way, i.e., by the implementation of an $\mathrm{Al}_{2} \mathrm{O}_{3}$ rear surface passivation layer with nanosized local point openings for contacting, as is shown in Fig. 1 [5], [6]. Initial studies indicate that this passivation layer reduces interface recombination by chemical (corresponding to a reduction in interface trap density) and field effect passivation (resulting from a fixed charge density in the passivation layer that reduces the surface minority or majority charge carrier concentration) [7], [8].

Further improvements in CZTSSe material quality are certainly desirable; nonetheless, early front surface passivation attempts have already been made. CZTSSe solar cell technology requires significant improvement as the record efficiency is $12.6 \%$ only, which is rather low compared with the $21.7 \%$ best CIGSSe efficiency [1]. Since CZTSSe technology is not as 


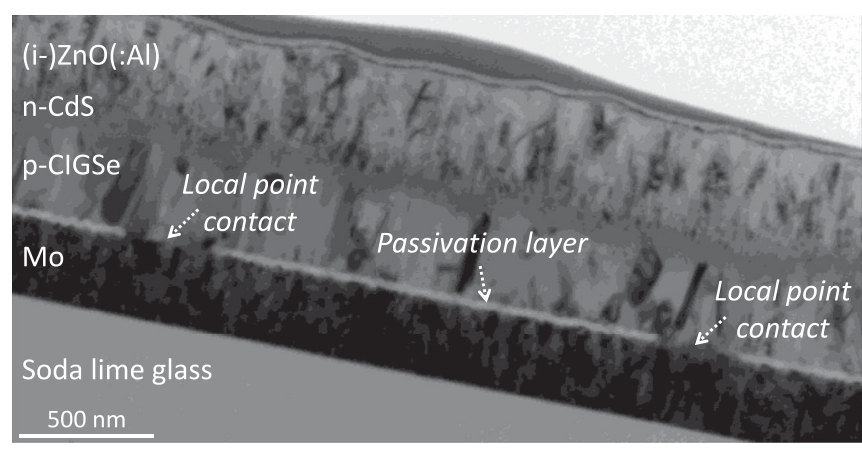

Fig. 1. TEM cross-sectional image of an $\mathrm{Al}_{2} \mathrm{O}_{3}$ rear surface passivated pure selenide CIGSe solar cell with a well-controlled grid of nanosized local rear point contacts [5], [6].

mature as CIGSSe [9], [10], there are still many difficulties that need to be addressed so that the electrical performance can be increased. Typical issues are secondary phase formation, fluctuating potentials, reproducibility and stability, and also cell architecture. Consequently, present research is mainly focused on enhancing the absorber quality [9], [10]. Nevertheless, interface passivation also deserves attention, as it has been verified that high-performing CZTSSe solar cells are dominated by interface recombination [11]. Initial efforts to improve the front absorber/buffer-layer interface have already been presented: First, also in CZTSSe solar cells, the influence of K incorporation on its properties has already been studied. This study showed that K doping can enhance the $\left(\begin{array}{lll}1 & 1 & 2\end{array}\right)$ preferred orientation, increase the grain size, and reduce the formation of $\mathrm{ZnS}$ secondary phases [12]. Second, also $\mathrm{TiO}_{2}$ front surface passivation layers have already been tried in CZTSSe solar cells. This passivation layer did not have nanosized point openings, but was thin enough so that the photoexcited electrons could effectively tunnel through the layer in the device [13].

In this work, for the first time, a novel rear surface passivation concept is integrated and studied in ultrathin pure sulfide CZTS solar cells. A prototypical method based on e-beam lithography, as previously developed for pure selenide CIGSe solar cells and shown in Fig. 1, is used to generate well-controlled grids of nanosized point openings in an $\mathrm{Al}_{2} \mathrm{O}_{3}$ passivation layer. This way, $\mathrm{Al}_{2} \mathrm{O}_{3}$ rear surface passivated CZTS solar cells with nanosized local rear point contacts are fabricated, and their performance and cross sections are studied and compared with unpassivated reference cells. Solar cells with ultrathin absorber layers are favored $(\leq 500 \mathrm{~nm})$, as these are ideal characterization devices to investigate charge carrier recombination at the rear CZTS surface (which becomes well assessable due to the short distance between the space charge region and the rear CZTS surface).

\section{EXPERIMENTAL DETAILS}

The $\mathrm{Al}_{2} \mathrm{O}_{3}$ rear surface passivated CZTS solar cell fabrication and characterization sequences are summarized in Table I; for more details concerning the nanostructured $\mathrm{Al}_{2} \mathrm{O}_{3}$ passivation layer formation, the general cell processing (e.g., the CZTS absorber layer formation), and a device model of unpassivated reference CZTS solar cells, see [6], [14], and [15].
TABLE I

Overview of All Steps Required to Fabricate $\mathrm{Al}_{2} \mathrm{O}_{3}$ REAR Surface PASSIVATED CZTS SOLAR CELlS WITH WELL-CONTROLLED GRIDS OF NANOSIZED LOCAL POINT CONTACTS

\begin{tabular}{|c|c|c|}
\hline Step & Description & Remarks \\
\hline Start & $\begin{array}{l}\text { Low iron soda lime } \\
\text { glass (SLG) }\end{array}$ & $1 \mathrm{~mm}$ thick \\
\hline 1 & Glass cleaning & $\begin{array}{l}\text { Deionized (DI) water and Cole-Palmer Micro-90 } \\
\text { detergent in ultrasonic bath at } 60^{\circ} \mathrm{C}\end{array}$ \\
\hline 2 & $\begin{array}{c}\text { Rear contact } \\
\text { deposition }\end{array}$ & DC-sputtering of Mo $0.6 \Omega / \square, 350 \mathrm{~nm}$ thick \\
\hline 3 & $\begin{array}{l}\text { Passivation layer } \\
\text { deposition }\end{array}$ & $D C$ or $R F$-sputtering of $\mathrm{Al}_{2} \mathrm{O}_{3}(30 \mathrm{~nm})$ \\
\hline 4 & $\begin{array}{l}\text { Creation of openings } \\
\text { in the passivation } \\
\text { layer }\end{array}$ & $\begin{array}{l}\text { E-beam pattern \& reactive ion etching } \mathrm{BCl}_{3} \\
400 \mathrm{~nm} \text { opening diameter, } 2 \mu \mathrm{m} \text { spacing, or } \\
180 \mathrm{~nm} \text { opening diameter, } 1 \mu \mathrm{m} \text { spacing. See [6] }\end{array}$ \\
\hline 5 & $\begin{array}{l}\text { Na precursor } \\
\text { deposition }\end{array}$ & Evaporation of $\mathrm{NaF} 5$ or $10 \mathrm{~nm}$ thick \\
\hline 6 & $\begin{array}{l}\mathrm{Cu}-\mathrm{Zn}-\mathrm{Sn}-\mathrm{S} \\
\text { deposition }\end{array}$ & $\begin{array}{l}\text { Reactive sputtering in mixed } \mathrm{Ar}: \mathrm{H}_{2} \mathrm{~S} \text { gas } \mathrm{CuS}, \mathrm{Zn} \text {, } \\
\text { and } \mathrm{Sn} \text { targets Substrate temperature of } 180^{\circ} \mathrm{C} 1.7 \\
\leq \mathrm{Cu} / \mathrm{Sn} \leq 1.8, \mathrm{Zn} /(\mathrm{Cu}+\mathrm{Sn}) \sim 0.4\end{array}$ \\
\hline 7 & Annealing & $\begin{array}{l}\text { Closed graphite box in tube furnace } 35 \mathrm{kPa} \text { static } \\
\mathrm{Ar} \text { atmosphere } 80 \mathrm{mg} \text { elemental S inclusive } 560^{\circ} \mathrm{C} \\
\text { for } 10 \mathrm{~min}\end{array}$ \\
\hline 8 & Absorber etching & $2 \mathrm{~min}$ in $5 \mathrm{wt} \% \mathrm{KCN}$ solution \\
\hline 9 & Buffer deposition & $\begin{array}{l}\text { Chemical bath deposition (CBD) of } \mathrm{CdS} 60^{\circ} \mathrm{C} \text {, } \\
50 \mathrm{~nm} \text { thick }\end{array}$ \\
\hline 10 & Window deposition & $\begin{array}{l}\text { RF-sputtering of (i-)ZnO(:Al) } 400 \mathrm{~nm} \text { thick, } \\
40 \Omega / \square\end{array}$ \\
\hline 11 & $\begin{array}{l}\text { Front contact } \\
\text { deposition }\end{array}$ & Evaporation of $\mathrm{Ni} / \mathrm{Al} / \mathrm{Ni} 400 / 3000 / 400 \mathrm{~nm}$ thick \\
\hline 12 & Solar cell scribing & Mechanical by use of a stylus four cells of $0.5 \mathrm{~cm}^{2}$ \\
\hline End & Characterization & $\begin{array}{l}\text { X-ray fluorescence (XRF) Raman scattering [16] } \\
\text { X-ray diffraction (XRD) [16] Profilometry } \\
\text { Scanning electron microscopy (SEM) } \\
\text { Transmission electron microscopy (TEM) } \\
\text { Energy-dispersive X-ray spectroscopy (EDX) } \\
\text { Standard light current versus voltage ( } J-V \text { ) } \\
\text { External quantum efficiency (EQE) }\end{array}$ \\
\hline
\end{tabular}

The unpassivated reference cells have the same processing sequence, but without steps 3 and 4 . A summary of all characterization techniques typically applied is also given.

\section{RESULTS AND DISCUSSION}

\section{A. CZTS Solar Cells With Ultrathin Absorber Layer as Characterization Devices}

Thinning down the absorber layer of standard CZTS solar cells results in reduced $V_{\mathrm{OC}}$ and $J_{\mathrm{SC}}$, because of a high rear interface recombination velocity and a reduced bulk quality (including the presence of secondary phases). Fig. 2 shows the average $V_{\mathrm{OC}}$ and $J_{\mathrm{SC}}$ of unpassivated reference CZTS solar cells with ever thinner absorber layers. Indeed, this figure illustrates a reduction in $V_{\mathrm{OC}}\left(-24 \%\right.$ rel.), $J_{\mathrm{SC}}(-27 \%$ rel.), $\mathrm{FF}(-9 \%$ rel.), and power conversion efficiency (PCE; -49\%rel.) if the CZTS absorber layer is reduced from 2000 down to $500 \mathrm{~nm}$. As all cell processing and X-ray fluorescence results are equivalent, absorber layer thickness $\left(t_{\mathrm{CZTS}}\right)$ should be the main variable for these cells. In that case, the most logical explanation for these $V_{\mathrm{OC}}$ and $J_{\mathrm{SC}}$ losses is a high recombination rate at the Mo/CZTS rear interface and incomplete absorption, respectively, which both become most obvious in the case of very thin absorber layers (as previously seen for CIGSe solar cells [5]). However, the overall picture is more complicated for these CZTS solar cells since experimental results also indicate that the thinnest CZTS layers are more sensitive to secondary phase segregation ( $\mathrm{SnS}$ and $\mathrm{ZnS}$ are observed at both the front surface of the CZTS 


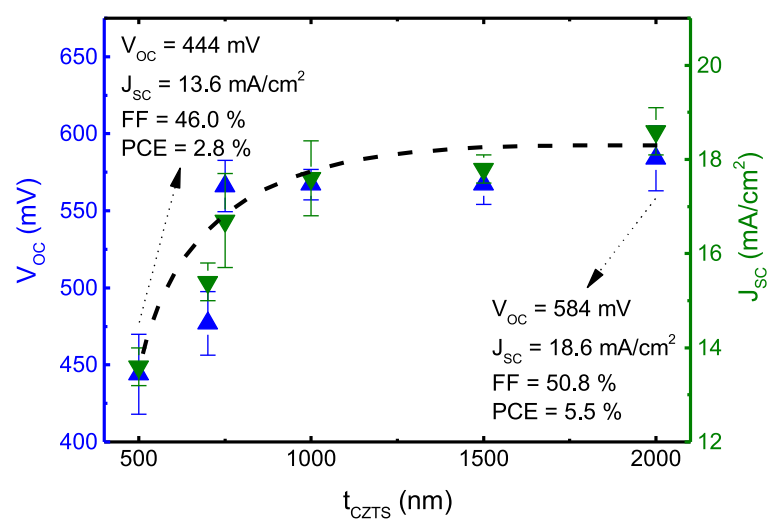

Fig. 2. Average open-circuit voltage and short-circuit current for unpassivated reference solar cells as a function of CZTS absorber layer thickness (eight cells per CZTS thickness). The standard deviation is shown as error bars, and the dashed line serves as a guide to the eye. Taken from [16].

films and the back contact interface) and nonuniform defect properties. These secondary phases can be detrimental to the device performance, since the $\mathrm{SnS}$ phase has a lower bandgap than CZTS phase and could modify the interface properties, while the $\mathrm{ZnS}$ phase can block current flow and introduce dead areas [16]. Indeed, using the Solar Cell Capacitance Simulator software, in-depth simulations have been performed and compared with these empirical data, indicating that the lower performance of the ultrathin CZTS solar cells is caused by both a reduced bulk quality and high rear interface recombination [17].

Introducing a rear surface passivation layer with nanosized local point contacts in such ultrathin CZTS solar cells has the potential to reduce the rear surface recombination velocity and the impact of secondary phase segregation significantly. As previously shown in ultrathin CIGSe solar cells [5]-[8], an adequate rear surface passivation layer leads to a low rear surface recombination velocity $(\leq 100 \mathrm{~cm} / \mathrm{s})$, resulting in a substantial $V_{\mathrm{OC}}$ and $J_{\mathrm{SC}}$ increase. Additionally, such a passivation layer with nanosized point contacts reduces the Mo/CZTS contacting area to about $2 \%$ of the total rear area (see Table I), which also means that the detrimental impact of $\mathrm{SnS}$ and $\mathrm{ZnS}$ secondary phases may be reduced. Hence, these solar cells with an ultrathin absorber layer $(\leq 500 \mathrm{~nm})$ are excellent study devices to investigate rear surface passivation layers in CZTS solar cells.

\section{B. $\mathrm{Mo}\left(/ \mathrm{Al}_{2} \mathrm{O}_{3}\right) /$ CZTS Rear Interface Study of Rear Passivated CZTS Solar Cells}

In this work, a $\mathrm{NaF}$ precursor layer is required to fabricate $\mathrm{Al}_{2} \mathrm{O}_{3}$ rear passivated CZTS solar cells, and-upon completion- the final passivation layer seems to be quite rough but present. An attempt to make rear passivated CZTS solar cells with point contacts but without the use of $\mathrm{NaF}$ precursor resulted in detachment of the absorber layer during the $\mathrm{KCN}$ etching step. Even more, another attempt to make rear passivated CZTS solar cells without point contacts but with the use of $\mathrm{NaF}$ precursor also resulted in similar peeling of the absorber layer during $\mathrm{KCN}$ etching. Hence, a NaF precursor and local point contacts (which thus seem to act as "anchoring points" for the CZTS absorber layer) are required to fabricate rear pas-

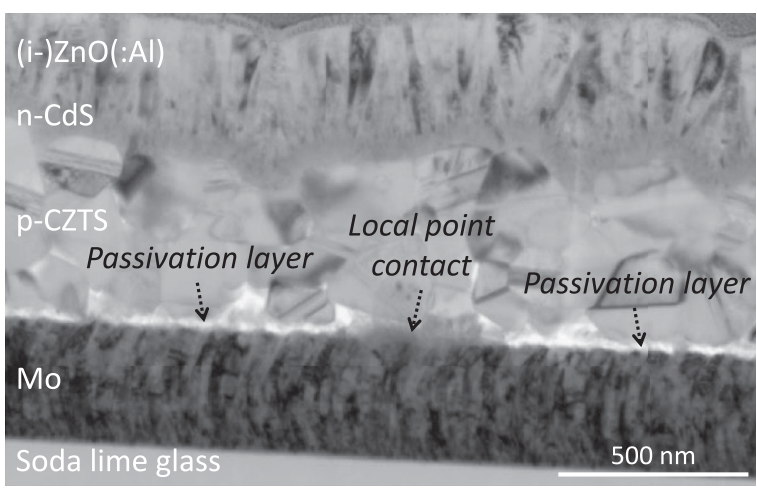

Fig. 3. TEM cross-sectional image of an $\mathrm{Al}_{2} \mathrm{O}_{3}$ rear surface passivated CZTS solar cell with a well-controlled grid of nanosized local rear point contacts.

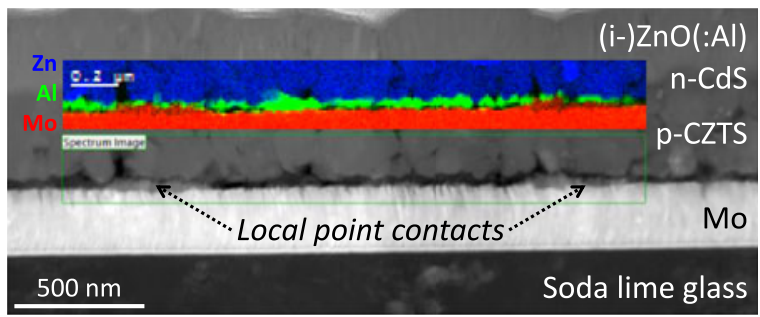

Fig. 4. TEM cross-sectional picture of an $\mathrm{Al}_{2} \mathrm{O}_{3}$ rear surface passivated CZTS solar cell with a well-controlled grid of nanosized local rear point contacts, including an EDX map for the elements $\mathrm{Zn}, \mathrm{Al}$, and $\mathrm{Mo}$ at the rear $\mathrm{Mo} /\left(\mathrm{Al}_{2} \mathrm{O}_{3} /\right) \mathrm{CZTS}$ interface.

sivated CZTS solar cells. Cross sections of such cells are shown in Figs. 3 and 4, displaying transmission electron microscopy (TEM) and energy-dispersive X-ray spectroscopy (EDX) measurements. In CIGSSe solar cells, Na doping has been shown to enhance film morphology, grain growth, conductivity, $V_{\mathrm{OC}}$, and FF, but the detailed processes have yet to be completely understood. Preliminary studies of Na doping of CZTSSe solar cells have already been performed and show improvements in film morphology, grain orientation, grain boundaries, shunt resistance, FF, $J_{\mathrm{SC}}$, and $V_{\mathrm{OC}}$ [18]. This work does not aim to study the fundamental impact of NaF precursors on CZTS solar cell performance; therefore, equivalent $\mathrm{NaF}$ precursors have been used in unpassivated reference solar cells. The TEM pictures shown in Figs. 3 and 4 noticeably display the $\mathrm{Al}_{2} \mathrm{O}_{3}$ rear surface passivation layer and its point openings, wherein $\mathrm{MoS}_{2}$ formation occurred. However, these pictures also show a few voids and it remains ambiguous to distinguish between these voids and the $\mathrm{Al}_{2} \mathrm{O}_{3}$. Therefore, in Fig. 4, an EDX map of this $\mathrm{Mo}\left(/ \mathrm{Al}_{2} \mathrm{O}_{3}\right) /$ CZTS rear interface region is shown, indicating that the $\mathrm{Al}_{2} \mathrm{O}_{3}$ passivation layer is fairly complete but quite rough compared with equivalent passivation layers in CIGSe solar cells (as, e.g., shown in Fig. 1). Indeed, it seems that by some means, chemical interaction occurs at the rear interface during sulfurization of the CZTS precursor, which could be expected as $\mathrm{Mo} / \mathrm{Al}_{2} \mathrm{O}_{3}$ is likewise used as sulfurization catalyst [19], [20]. However, also this study is outside the scope of this work, where the $\mathrm{Al}_{2} \mathrm{O}_{3}$ layer shown in Figs. 3 and 4 is satisfactory to study its effect as rear surface passivation layer in 
TABLE II

AVERAGe Values and STANDARD DEVIaTION OF CELl CharaCterization RESUlts (AM1.5 G) FOR 0.5-CM ${ }^{2} \mathrm{AL}_{2} \mathrm{O}_{3}$ REAR SURFACE PASSIVATED ULTRATHIN (400 NM) CZTS SOLAR CELLS AND CORRESPONDING UNPASSIVATED UltRATHIN AND THICK (2000 NM) REFERENCE CELLS

\begin{tabular}{|c|c|c|c|c|c|}
\hline [CZTS; pass.; pitch; $\mathrm{NaF}]$ & \# cells & $\begin{array}{l}V_{\mathrm{OC}} \\
(\mathrm{mV})\end{array}$ & $\underset{\left(\mathrm{mA} / \mathrm{cm}^{2}\right)}{J_{\mathrm{SC}}}$ & $\mathrm{FF}(\%)$ & $\operatorname{PCE}(\%)$ \\
\hline [Thin; N.A.; N.A.; 5 nm] & 4 & $\begin{array}{l}461 \\
\pm 53\end{array}$ & $\begin{array}{c}14.7 \\
\pm 0.6\end{array}$ & $\begin{array}{l}45.6 \\
\pm 4.4\end{array}$ & $\begin{array}{c}3.1 \\
\pm 0.3\end{array}$ \\
\hline [Thin; $\left.\mathrm{Al}_{2} \mathrm{O}_{3} ; 2 \mu \mathrm{m} ; 5 \mathrm{~nm}\right]$ & 4 & $\begin{array}{c}540 \\
\pm 09\end{array}$ & $\begin{array}{c}15.4 \\
\pm 0.2\end{array}$ & $\begin{array}{c}49.9 \\
\pm 0.7\end{array}$ & $\begin{array}{c}4.1 \\
\pm 0.1\end{array}$ \\
\hline$\left[\right.$ Thin; $\left.\mathrm{Al}_{2} \mathrm{O}_{3} ; 1 \mu \mathrm{m} ; 5 \mathrm{~nm}\right]$ & 4 & $\begin{array}{c}540 \\
\pm 30\end{array}$ & $\begin{array}{c}13.6 \\
\pm 0.2\end{array}$ & $\begin{array}{c}43.8 \\
\pm 3.4\end{array}$ & $\begin{array}{c}3.2 \\
\pm 0.2\end{array}$ \\
\hline [Thin; $\left.\mathrm{Al}_{2} \mathrm{O}_{3} ; 2 \mu \mathrm{m} ; 10 \mathrm{~nm}\right]$ & 4 & $\begin{array}{c}522 \\
\pm 05\end{array}$ & $\begin{array}{c}15.2 \\
\pm 0.1\end{array}$ & $\begin{array}{c}42.9 \\
\pm 3.0\end{array}$ & $\begin{array}{c}3.4 \\
\pm 0.3\end{array}$ \\
\hline [Thick; N.A.; N.A.; 0 nm]* & 8 & $\begin{array}{c}584 \\
\pm 21\end{array}$ & $\begin{array}{c}18.6 \\
\pm 0.5\end{array}$ & $\begin{array}{c}50.8 \\
\pm 4.1\end{array}$ & $\begin{array}{c}5.5 \\
\pm 0.6\end{array}$ \\
\hline
\end{tabular}

The rear passivation layers have a well-controlled grid of nanosized local point openings with a pitch of 1000 or $2000 \mathrm{~nm}$.

*taken from [16].

CZTS solar cells with ultrathin (and, thus, lower bulk quality [16]) absorber layers.

\section{Analysis of the Rear Passivated CZTS Solar Cell Results Compared With Corresponding Unpassivated Reference Cells}

Ultrathin CZTS solar cells with a nanostructured $\mathrm{Al}_{2} \mathrm{O}_{3}$ rear surface passivation layer have been fabricated and show reduced rear surface recombination and enhanced optical confinement, as compared with corresponding unpassivated reference cells. Table II gives an overview of measured ultrathin CZTS solar cells $\left(t_{\text {CZTS }}=400 \mathrm{~nm}\right)$ with and without an $\mathrm{Al}_{2} \mathrm{O}_{3}$ rear surface passivation layer having nanosized point openings, but also thick $\left(t_{\text {CZTS }}=2000 \mathrm{~nm}\right)$ unpassivated reference cells (taken from [16]). Representative $J-V$ and EQE curves for these cells are presented in Fig. 5(a) and (b), respectively. Note that the ultrathin unpassivated reference cell measurements with $t_{\mathrm{CZTS}}=400 \mathrm{~nm}$ show slight improvements in FF, $J_{\mathrm{SC}}$, and $V_{\mathrm{OC}}$ compared with the results obtained in Fig. 2, as expected due to the use of $5 \mathrm{~nm}$ of NaF precursor [18]. First, this discussion will concentrate on the $\mathrm{Al}_{2} \mathrm{O}_{3}$ rear passivated cells with a pitch (distance between the point openings) of $2 \mu \mathrm{m}$, and where $5 \mathrm{~nm}$ of $\mathrm{NaF}$ is used. As shown in Table II, $V_{\mathrm{OC}}\left(+17 \%\right.$ rel.), $J_{\mathrm{SC}}$ (+5\% rel.), FF (+ 9\% rel.), and PCE (+32\%rel.) are positively impacted in these rear passivated cells, as compared with corresponding unpassivated reference cells. The conceivable reasons are 1) a reduction in rear surface recombination velocity due to the passivation effect of the $\mathrm{Al}_{2} \mathrm{O}_{3}$ layer (chemical and field effect passivation [5]-[7]) and 2) a reduced impact of the SnS and $\mathrm{ZnS}$ secondary phases due to the reduced rear contacting area (merely $2 \%$ of the total rear surface is contacting area). Additional interpretations can be made from Fig. 5: 1) The series resistance $\left(R_{\mathrm{S}}\right)$ has been estimated from the one-diode model, indicating an increase from 1.1 to $14.2 \Omega \cdot \mathrm{cm}^{2}$ for the rear passivated cells, compared with their corresponding reference cells, as expected from the shape of the $J-V$ curves. Even more, the $J_{-}$ $V$ curve of this rear passivated cell also shows a slight "roll-over" effect, which could be caused by a lack of $\mathrm{Na}$ or a barrier effect [5]. Indeed, the used $\mathrm{Al}_{2} \mathrm{O}_{3}$ passivation layer largely blocks $\mathrm{Na}$ diffusion from the substrate ([5], which could result in $\mathrm{Na}$

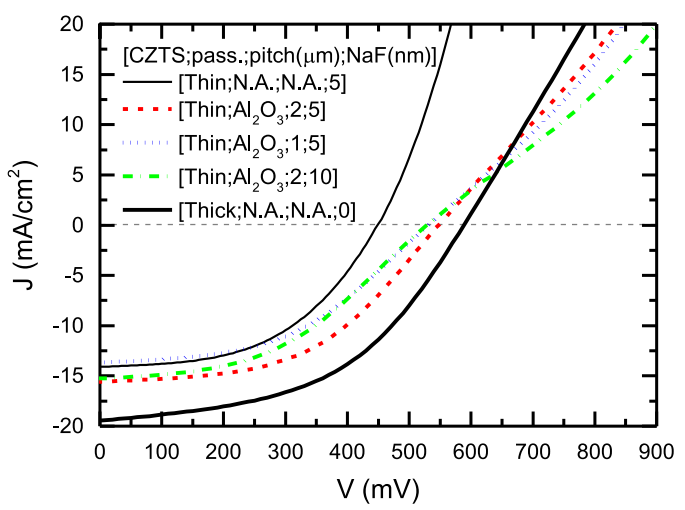

(a)

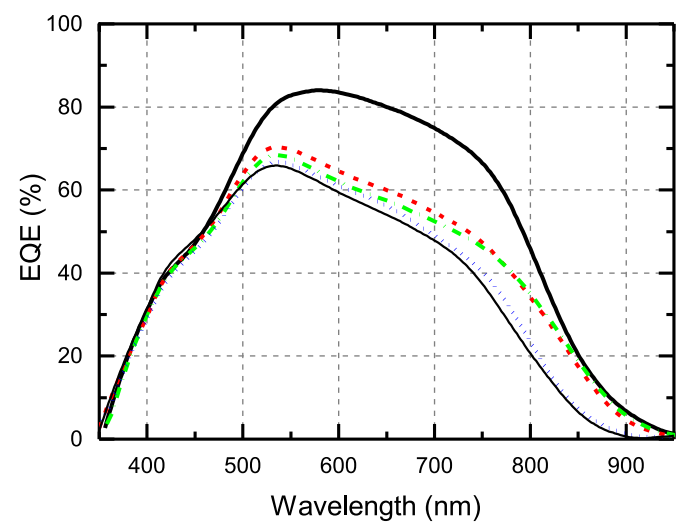

(b)

Fig. 5. Representative (a) current-voltage and (b) external quantum efficiency curves for $\mathrm{Al}_{2} \mathrm{O}_{3}$ rear surface passivated ultrathin $\left(t_{\mathrm{CZTS}}=400 \mathrm{~nm}\right)$ CZTS solar cells and corresponding unpassivated ultrathin and thick $\left(t_{\mathrm{CZTS}}=\right.$ $2000 \mathrm{~nm}$, taken from [16]) reference cells. The rear passivation layers have a well-controlled grid of nanosized local point openings with a pitch of 1 or $2 \mu \mathrm{m}$. All EQE spectra are smoothed using a 50-point Savitzky-Golay smoothing filter.

deficient solar cells), and the distance between its point openings could be too large (and as a result, it acts as a barrier layer). 2) Compared with corresponding reference cells, the rise in $J_{\mathrm{SC}}$ in the rear passivated CZTS cells is mainly realized at higher wavelengths (from about 700 to $900 \mathrm{~nm}$ ), while this wavelength range was much broader for rear passivated CIGSe solar cells (from about 550 to $1050 \mathrm{~nm}$; see, e.g., [6]). This difference could be related to the formation of secondary phases at the front and rear of ultrathin CZTS absorbers, an issue not present in the CIGSe solar cells, or to the shorter diffusion length of CZTS absorbers. Indeed, the passivation layer with nanosized point openings is effective in reducing the impact of $\mathrm{ZnS}$ and $\mathrm{SnS}$ secondary phase segregation but primarily at the rear CZTS interface, and the electron diffusion length is anticipated to be between 250 and $500 \mathrm{~nm}$ only (from the simulations performed in [15]-[17]). Note that - possibly - these EQE curves may even provide an opportunity to distinguish between bulk and rear interface improvement of the rear passivation layer in ultrathin CZTS solar cells. Second, the other rear passivated solar cells will be discussed. As mentioned before, the $\mathrm{Al}_{2} \mathrm{O}_{3}$ rear passivated cells with a pitch of $2 \mu \mathrm{m}$ and $5 \mathrm{~nm}$ of $\mathrm{NaF}$ show high $R_{\mathrm{S}}$ and might be slightly Na deficient or have too large of a pitch. Therefore, rear passivated cells with smaller pitch $(1 \mu \mathrm{m})$ and thicker $\mathrm{NaF}$ $(10 \mathrm{~nm})$ are also prepared. Despite a significant increase in $V_{\mathrm{OC}}$ 
compared with the corresponding unpassivated reference cells, no decrease in $R_{\mathrm{S}}$ or " $J-V$ roll-over" is obtained, compared with the rear passivated cells with $2-\mu \mathrm{m}$ pitch and 5-nm Na. Contrarily, Fig. 5(a) shows an increase in $R_{\mathrm{s}}$ and even more " $J-V$ roll-over" both for smaller pitch and thicker $\mathrm{NaF}$, resulting in a $J_{\mathrm{SC}}$ and FF reduction. Hence, two final remarks can be made: 1) As the charge carrier diffusion lengths are anticipated to be short (laterally, it might even be lower due to recombination at grain boundaries), a pitch of $1 \mu \mathrm{m}$ is probably still too large. Thus, the slight roll-over seen in the $J-V$ curves of the rear passivated cells could be an indication of a barrier layer between the rear contact and absorber, which would make sense in the case of a too short diffusion length combined with a point contact spacing that is too wide. Note that such short diffusion lengths also designate that characterization devices with a CZTS thickness of $400 \mathrm{~nm}$ are still on the thick side to study rear interface recombination. 2) Using a thicker $\mathrm{NaF}$ layer did not diminish the " $J-V$ roll-over," but then again, it remains difficult to draw Na-related conclusions as the influence of $\mathrm{NaF}$ and its thickness on the fabrication of CZTS solar cells is not fully understood and requires more investigation.

\section{CONCLUSION AND OutloOK}

An $\mathrm{Al}_{2} \mathrm{O}_{3}$ rear surface passivation layer is established and studied in CZTSSe solar cells, where it provides a positive impact on cell performance. Rear passivated pure sulfide CZTS TF solar cells with nanosized point openings have been fabricated, which showed a clear increase in $V_{\mathrm{OC}}, J_{\mathrm{SC}}, \mathrm{FF}$, and, hence, efficiency, as compared with corresponding reference cells. These cells have ultrathin $\left(t_{\mathrm{CZTS}}=400 \mathrm{~nm}\right)$ absorber layers and, therefore, are exemplary characterization devices to investigate rear interface recombination. The reasons for the improvement in cell performance are a reduction in 1) charge carrier recombination at the rear absorber surface and 2) the impact of secondary phase segregation. Theoretically, this approach could also be interesting for CZTS solar cells with thicker absorber layers if these would exhibit long diffusion lengths, which - unfortunately - is not yet the case.

This is a very promising result, but better understanding is essential. Therefore, new experiments (fabrication of solar cells, but also simplified test devices for optoelectrical characterization [7], [8]) with alternative passivation layers and reduced point contact spacing are scheduled.

Note that layer deposition techniques and methods to generate nanosized features appropriate for upscaling do exist, in case such passivation layers with nanosized point openings would become tempting for industrial application. For the deposition of passivation layers, one could think of spatial ALD [21], [22], or lower quality deposition methods such as sputtering or plasmaenhanced chemical vapor deposition [23], [24], while hole colloidal lithography and nanoimprint lithography in combination with either dry or wet chemical etching have industrial potential for nanostructuring [25].

\section{REFERENCES}

[1] M. A. Green, K. Emery, Y. Hishikawa, W. Warta, and E. D. Dunlop, "Solar cell efficiency tables (version 45)," Prog. Photovoltaics: Res. Appl., vol. 23, no. 1, pp. 1-9, 2015.
[2] Y. Fu et al., "ZnS nanodot film as defect passivation layer for $\mathrm{Cu}(\mathrm{In}, \mathrm{Ga})(\mathrm{S}, \mathrm{Se})_{2}$ thin-film solar cells deposited by spray-ILGAR (ionlayer gas reaction)," Adv. Energy Mater., vol. 1, no. 4, pp. 561-564, 2011.

[3] P. Reinhard et al., "Alkali-templated surface nanopatterning of chalcogenide thin films: A novel approach toward solar cells with enhanced efficiency," Nano Lett., vol. 15, no. 5, pp. 3334-3340, 2015.

[4] P. Reinhard et al., "Cu(In,Ga)Se e $_{2}$ thin-film solar cells and modules-A boost in efficiency due to potassium," IEEE J. Photovoltaics, vol. 5, no. 2, pp. 656-663, Mar. 2015.

[5] B. Vermang, V. Fjällström, X. Gao, and M. Edoff, "Improved rear surface passivation of $\mathrm{Cu}(\mathrm{In}, \mathrm{Ga}) \mathrm{Se}_{2}$ solar cells: A combination of an $\mathrm{Al}_{2} \mathrm{O}_{3}$ rear surface passivation layer and nanosized local rear point contacts," IEEE J. Photovoltaics, vol. 4, no. 1, pp. 486-492, Jan. 2014.

[6] B. Vermang et al., "Introduction of Si PERC rear contacting design to boost efficiency of $\mathrm{Cu}(\mathrm{In}, \mathrm{Ga}) \mathrm{Se}_{2}$ solar cells," IEEE J. Photovoltaics, vol. 4, no. 6, pp. 1644-1649, Nov. 2014.

[7] R. Kotipalli et al., "Investigating the electronic properties of $\mathrm{Al}_{2} \mathrm{O}_{3} / \mathrm{Cu}(\mathrm{In}, \mathrm{Ga}) \mathrm{Se}_{2}$ interface," $A I P A d v$., vol. 1, no. 5, pp. 1071011-107101-6, 2015.

[8] J. Joel, B. Vermang, J. Larsen, O. Donzel-Gargand, and M. Edoff, "On the assessment of CIGS surface passivation by photoluminescence," Phys. Status Solidi RRL, vol. 9, no. 5, pp. 288-292, 2015.

[9] I. L. Repins et al., "Kesterite successes, ongoing work, and challenges: A perspective from vacuum deposition," IEEE J. Photovoltaics, vol. 3, no. 1, pp. 439-445, Jan. 2013.

[10] A. Redinger et al., "Route toward high-efficiency single-phase $\mathrm{Cu}_{2} \mathrm{ZnSn}(\mathrm{S}, \mathrm{Se})_{4}$ thin-film solar cells: Model experiments and literature review," IEEE J. Photovoltaics, vol. 1, no. 2, pp. 200-206, Oct. 2011.

[11] D. A. R. Barkhouse, O. Gunawan, T. Gokmen, T. K. Todorov, and D. B. Mitzi, "Device characteristics of a $10.1 \%$ hydrazine-processed $\mathrm{Cu}_{2} \mathrm{ZnSn}(\mathrm{Se}, \mathrm{S})_{4}$ solar cell," Prog. Photovoltaics: Res. Appl., vol. 20, no. 1, pp. 6-11, 2012.

[12] Z. Tong et al., "Effects of potassium doping on solution processed kesterite $\mathrm{Cu}_{2} \mathrm{ZnSnS}_{4}$ thin film solar cells," Appl. Phys. Lett., vol. 105, pp. 2239031-223903-4, 2014.

[13] W. Wu et al., "Characterization of CZTSSe photovoltaic device with an atomic layer-deposited passivation layer," Appl. Phys. Lett., vol. 105, pp. 042108-1-042108-4, 2014.

[14] Y. Ren, J. J. Scragg, T. Ericson, T. Kubart, and C. Platzer-Björkman, "Reactively sputtered films in the $\mathrm{Cu}_{\mathrm{x}} \mathrm{S}-\mathrm{ZnS}-\mathrm{SnS}_{\mathrm{y}}$ system: From metastability to equilibrium," Thin Solid Films, vol. 582, pp. 208-214, 2015.

[15] C. Frisk et al., "Combining strong interface recombination with bandgap narrowing and short diffusion length in CZTS device modeling," Sol. Energy Mater. Sol. Cells, vol. 144, pp. 364-370, 2015.

[16] Y. Ren et al., "Influence of the $\mathrm{Cu}_{2} \mathrm{ZnSnS}_{4}$ absorber thickness on thin film solar cells,” Phys. Status Solidi A, 2015, DOI: 10.1002/pssa.201532311.

[17] C. Frisk, Y. Ren, S. Li, and C. Platzer-Björkman, "CZTS solar cell device simulations with varying absorber thickness," in Proc. 42nd IEEE Photovoltaic Spec. Conf., 2015.

[18] A. D. Collord, H. Xin, and H. W. Hillhouse, "Combinatorial exploration of the effects of intrinsic and extrinsic defects in $\mathrm{Cu}_{2} \mathrm{ZnSn}(\mathrm{S}, \mathrm{Se})_{4}$," IEEE J. Photovoltaics, vol. 5, no. 1, pp. 288-298, Jan. 2015.

[19] M. Tang et al., "Presulfidation and activation mechanism of $\mathrm{Mo} / \mathrm{Al}_{2} \mathrm{O}_{3}$ catalyst sulfided by ammonium thiosulfate," Korean J. Chem. Eng., vol. 31, no. 8, pp. 1368-1376, 2014.

[20] T.-M. Chen, C.-M. Wang, I. Wang, and T.-C. Tsai, "Promoter effect of vanadia on $\mathrm{Co} / \mathrm{Mo} / \mathrm{Al}_{2} \mathrm{O}_{3}$ catalyst for deep hydro-desulfurization via the hydrogenation reaction pathway," J. Catalysis, vol. 272, pp. 28-36, 2010.

[21] (2015, Sep. 7). The InPassion ALD Tool. [Online]. Available: http://www. solaytec.com/

[22] (2015, Sep. 7). The Levitrack ALD System. [Online]. Available: http:// www.levitech.nl/

[23] B. Vermang et al., "Employing Si solar cell technology to increase efficiency of ultra-thin $\mathrm{Cu}(\mathrm{In}, \mathrm{Ga}) \mathrm{Se}_{2}$ solar cells," Prog. Photovoltaics: Res. Appl., vol. 22, no. 10, pp. 1023-1029, 2014.

[24] G. Dingemans and W. M. M. Kessels, "Review: status and prospects of $\mathrm{Al}_{2} \mathrm{O}_{3}$-based surface passivation schemes for silicon solar cells," $J$. Vac. Sci. Technol. A, vol. 30, no. 4, pp. 040802-1-040802-27, 2012.

[25] C. Trompoukis et al., "Photonic nanostructures for advanced light trapping in thin crystalline silicon solar cells," Phys. Status Solidi (a), vol. 212, no. 1 , pp. 140-155, 2015. 